\title{
Politics and Self in the Age of Digital (Re)producibility
}

\author{
Robert W. Williams
}

Globalization is very much about individuals and freedom - a claim all the more reinforced by some politicians in the face of international terrorism. Freedom, often framed as the capacity to think and act autonomously, is an essential characteristic of the individual in many liberal-democratic and neo-classical economic theories. The globalization of liberal-democratic values and market principles, it is often asserted, brings with it a bright future for individuals around the world and their freedoms. But, as this work argues, globalization does not necessarily yield all of thepositive consequences so loudly heralded for individuality.

The individual in Western philosophical and political theories, especially after René Descartes, is theorized as the discrete self. That is to say, the essential part of the individual is the self, the unique and fundamentally autonomous entity in Western value systems. As analyzed by various conventional Western social sciences, the self is fundamental to our humanity: it is how we organize our personal experiences and it is the basis for our reflexive action in the world. In economics, the self is the agent of instrumentally rational decision-making. In political science, the self can be defined as the citizen who participates via voting or other political activities. In legal analysis, the self is the agent who is ultimately responsible for his/her behavior within society.

Common to the dominant conceptions of the individual self in Western social sciences are its distinctive properties of naturalness and non-reducibility. Such characteristics derive from the dominant Western values out of which the social sciences emerged, such as the social contract theories of Thomas Hobbes and John Locke and the works of the Scottish Enlightenment by Adam Smith and Bernard Mandeville (see Smith 1997). In liberaldemocratic polities the citizen is the entity with selfhood and its attendant inalienable rights. In a market economy, the individual is the optimizer of costs and benefits in his/her interests and accordingly is "self-contained," i.e., the only one capable of so ascertaining personal interests. Certainly, the formation of the self is studied with regard to larger social(izing) processes, especially with regard to its subjectivity (i.e., a content of the self, like identity). For example, theoretical frameworks like! symbolic interactionism consider that the self is formed in relation to others in society (see Sandstrom et al. 2001). The self, nevertheless, retains its aura of authenticity and its irreducible sanctitythat is, its putative individuality - in many Western value systems.

It is just such irreducibility and authenticity of the individual self that this work tackles. I seek to advance the argument made by Gilles Deleuze through his concept of the "dividual" — a physically embodied human subject that is endlessly divisible and reducible to data representations via the modern technologies of control, like computerbased systems. I offer an immanent critique of the self, specifically focusing on the relationship between the self and digital technology. Such technology is crucial to globalization, and points towards the Internet and its cyberspaces as the terrain ultimately to be examined in this paper.

Deleuze offers us a conceptual point of departure. His notion of the dividual grasps a vital part of the dynamics of modern technology: the intersection of human agency and high-technology in the constitution of selves. Deleuze allows us to extend the analysis of individuality derived from such thinkers as Max Horkheimer and Theodor Adorno in Dialectic of Enlightenment (1973), Erich Fromm in Escape from Freedom (1965), and Herbert Marcuse in OneDimensional Man (1964). With a concept of dividuality we can address the complexity of a global(izing) society with is characteristic digital forms of communication and its cyberspaces. Hence, Deleuze's concept will be theoretically 
extended.

The paper advances a central theme: there is a dialectic of in/dividuality present in the conjuncture of globalizing capitalism and liberal-democratic policies. The relationships that reduce us as separate selves to digitally mediated signifiers and that "reproduce" those signifiers as dividuals also provide the potential for resistance against the oppressions resulting from digital re(pro)ducibility. Specifically, the very digitality that engenders oppression also gives rise to, and facilitates the practices of, new forms of opposition to the globalizing forces themselves. Accordingly, we also will have the opportunity to exercise reason in the promotion of the social good. We might be able thereby to practice the autonomy of reason so often touted in traditional conceptions of individuality. Herein the dynamics of in/dividuality will be examined with regard to cyberspace, at once a digitally created environment of the Internet as well as a vital terrain of resistance in the 21 st century.

Certainly, many have theorized the effects and consequences of digital technology on humans and society. The rise of digital communications and automation has generated analyses gushing with optimistic forecasts. In keeping with this paper's focus on Internet-related technologies, we find the following included among the suggested advantages: the efficient provision of government services, the ease of conducting commerce, the creation of new communities, and the enhancement of communication across political borders and physical distance (e.g., see Bowman 2003; Negroponte 1995; Tsagarousianou et al. 1998; Weare et al. 1999). There are, however, also somber analyses filled with pessimistic conclusions about cyberpolitics. Such include arguments that Internet communities do not replicate the old-style public spaces of democracy, that human isolation and parochialism of views can be reinforced, and that political deliberation is weakened via cyberpolitics (e.g., Goldberg 1999; Ornstein 2000; Saco 2002; Sunstein 2001).

My analysis attempts to thread its way between the extreme cases. How should we theorize the emancipatory potentials of the Internet in the service of struggles against various forms of oppression (whether racial, class, gender, ableist, sexual, etc.)? As such, the paper sets forth the conditions for the positive use of cyberspace and cyberactivism, while also enumerating some of the crucial structural constraints on such activism.

To pursue such emancipatory goals I ground my analysis squarely within the Marxian tradition, especially within its broad Western strand. In particular, I utilize immanent critique as my central methodological tool. Immanent critique is a dialectical approach to social inquiry associated with the so-called Frankfurt School (Jay 1973; Morrow 1994; Wiggershaus 1995). Immanent critique as a tool evaluates a taken-for-granted phenomenon or concept with reference to the social preconditions that constitute it. As such, immanent critique will seek to explore the underlying assumptions as well as any contradictions between the concept or phenomenon, on the one hand, and the reality of its manifestations, on the other (see, for example, Antonio 1981; Morrow 1994). To quote Max Horkheimer, immanent critique relates

social institutions and activities to the values they themselves set forth as their standards and ideals. .... If subjected to such an analysis, the social agencies most representative of the present pattern of society will disclose a pervasive discrepancy between what they actually are and the values they accept. To take an example, the media of public communication, radio, press, and film, constantly profess their adherence to the individual's ultimate value and his inalienable freedom, but they operate in such a way that they tend to foreswear such values by fettering the individual to prescribed attitudes, thoughts, and buying habits. (Horkheimer 1989: 265).

Immanent critique, in brief, seeks to discover the taken-for-granted aspects of a theoretical or ideological position and thereby bring to light their implications and consequences for the life chances of humans.

My self-positioning within the Western Marxist tradition is quite evident also in the value placed, implicitly or explicitly, on the reasoned agency of humans in the struggles against social oppressions. Humans and human identity are not the unitary, rational, self-evident selves conceptualized by the Enlightenment. But neither are humans mere conscious-less objects to be tossed about by larger, impersonal forces. Indeed, humans can be "sutured" together with different and potentially conflicting claims on identity (Laclau and Mouffe 1985). Such, nevertheless, does not foreclose the capacity of humans to reason, act, and organize into societies; in short, human have the potential to discover, deliberate, and create common values and shared goals.

\section{| Problematizing the Individuality of the Self}

How distinctly and utterly "individual" is the self? This is a salient question in a world of ever-globalizing capitalism with its forces that affect our daily lives, and thereby exert influence on our selves. The conceptual boundaries that 
constitute the putative distinctiveness of our individuality are affected by the marketing and targeting of our selves as consumers of goods and services. Nowadays, marketing is not only directed as the "masses" but also includes the "niche-targeting" of consumers. Mass marketing involves the advertisement of consumer goods to all people as a more-or-less undifferentiated mass (albeit in terms of some distinctions, e.g., advertisements for gender-specific clothing in gender-related venues). Information is not gathered for specific consumers; rather, advertisements are presented "spectacularly" for people to view or hear. Niche targeting, however, locates those consumers that might "want" particular products or particular brands of products (Klein 2000). This requires that data will be gathered, stored, and analyzed - processes facilitated by the expansion of new digital technologies.

To promote the pursuit of our "individual" desires, our demographic information is gathered into data banks, our Internet surfing preferences are stored as "cookies" that we accept when visiting Web sites, and our grocery purchases are monitored at check-outs so as to yield coupons on related items for later use. Such actions are trumpeted as positive. They make our consumption more efficient because relevant goods and services are proffered for sale, are displayed for easier selection, or are offered for edification and entertainment. So-called "personalization technologies" are common (Negroponte 1995): Amazon.com suggests other books to buy based on what books we key in as search terms, and TiVo tapes TV and cable shows for later viewing based on previous shows watched by the subscriber (Zaslow 2002). Certainly, numerous advertisements shout out how "we can have it our way." If we believe the hype, there has never been a better time for our selves and our unique individualities.

Individuality is also the rallying cry of liberal-democratic governments charged with preserving societal order, national security, and the personal liberties of individuals. The latter are broadly inclusive of a varied mixture of civil and political freedoms as well as the rights to property and to privacy. The violence to individuality emerges when considering how both socio-political order/security and personal liberties are implemented in practice. Surveillance has been a major means used by governmental institutions both to secure societal order and to protect the safety of individuals (Lyon 1994). Surveillance includes not only observation, but also record keeping of the information gathered. Over time, government surveillance has increased as a response to major societal disruptions like civil unrest, economic depression, and wars. Most recently surveillance has been amplified after the September 11th terrorist acts. But when viewed historically, such increases in government surveillance are also part of trend that intensified in the wake of policy reforms which institutionalized the so-called managerial state and its welfare-state variant of the post-World War II capitalism (Lyon 1994).

As many mainstream pundits might argue, compromises often must be struck between the extremes of societal order and individuality. Nonetheless, problems have emerged when the same management techniques and values used by government agencies in the interests of managing a capitalist economy system (e.g., efficiency pursued via instrumentally rational means) are likewise used to manage the citizens. In such instances individuals are paternalistically administered as "clients" of a system that denies them some of the supposed autonomy of a sovereign self. Moreover, governmental policies to support social order can potentially threaten individuality, especially in its senses of civil and political freedoms and of privacy. For example, critics of the administration of U.S. President George W. Bush hold that it is not maintaining the proper protections of individual civil liberties and privacy in its war against global terrorism (Amnesty International 2002; Chang 2001; Cole and Dempsey 2002; Katyal 2001; Lyon 2001). As a practical consequence, social and political dissent, even peaceful forms of protest, against hegemonic values and practices has been, is being, and will continue to be, surveiled in the interests of order.

Thus we must ask: how individual is the self when it too is marketed and targeted by government organizations? How autonomous, sacrosanct, and centered is the individual when autonomy is defined as choosing from pre-selected political or consumer choices? When we are buffeted by multiple claims on our identity (such as the particularity of nationalism which can contravene the universals of humanitarianism)? When pandering to our psychological and physical fears are central features of marketing (whether for political or corporate campaigns)? When material inequities diminish our capacity to achieve our highest aspirations (aspirations which themselves are often defined in terms of buying consumer goods)? All such questions interrogate the pre-given naturalness of monadic conceptions of individuals and thereby point us to the social construction of the content of what makes us individuals.

To criticize individuality as everywhere influenced by larger social forces and thereby "unnatural" is not to abandon agency by a socially engaged self. Many attacks have been launched against the presumed individualism at the heart of our socio-economic order, including its consumer sovereignty. Certainly, the individual self as a foundational, stable subjectivity with its hetero-normative, masculinist, and elitist biases has been criticized as a construct of Western philosophy from a variety of structuralist, Marxist, poststructuralist, and feminist perspectives 
(see, e.g., Althusser 1971; Foucault 1978; Harding 1995; Rich 1986). Nonetheless, I wish to preserve a notion of self / selves so as to retain a way to theorize human agency in the world.

Agency refers to that capacity of our selves to act reflexively, meaningfully, and responsibly, if not always effectively or efficiently (Barnes 2001). Agency is integral to our selves, whether we accept the Marxian tenet that we make history but not always as we want, or follow the Sartrean existentialist dictum that we must always choose to act because we are never free to do otherwise. Wherever and whenever we go, there and then we are and do- $\mathrm{knitted}$ together as we may be with multiple, interwoven, and overlapping identities and claims to identities. Our selves embody agency in social space and time, and are evinced as disembodied avatars in the virtual realms of cyberspace.

Technology and human agency are intertwined historically; or we can argue that human agency is technologically mediated. We humans create tools and technological systems to do our intentional and conscious bidding. As de Beauvoir wrote, technology helps us to distinguish ourselves from each other and from the environment (de Beauvoir 1972). Moreover, our selves express (moral) agency in how we use technology and for what ends — and in some cases, how we choose not to use some technologies, like weapons of torture and destruction. As mediation, technology however is not without its shaping influences on human life chances, as I discuss later.

Technology promises new ways to act and be human, especially in the digital realms of cyberspace. But before elaborating on those possibilities let me first explore the problematic aspects of technology as a mediation of human agency.

\section{| Deleuze's Concept of the "Dividual"}

A prolific social theorist and philosopher, Gilles Deleuze sought new ways to theorize the potential for emancipation in an epoch where neither the proletariat nor the bourgeoisie were the historical agents of liberation (see Patton 2001). In his short, suggestive essay, "Postscript on the Societies of Control," Deleuze sets forth his analysis of how we are controlled by technologies (Deleuze 1992). He continues Michel Foucault's project begun in such works as Discipline and Punish (Foucault 1978).

Foucault's disciplinary societies employed technologies, like factory assembly lines or hospital organizational structures, that physically placed people in time and space. By so doing, such institutional arrangements controlled their people. With reference to the panopticon, an architecture of surveillance discussed by Jeremy Bentham, Foucault wrote:

Power has its principle not so much in a person as in a certain concerted distribution of bodies, surfaces, lights, gazes; in an arrangement whose internal mechanisms produce the relation in which individuals are caught up. [....] So [with the panopticon] it is not necessary to use force to constrain the convict to good behaviour, the madman to calm, the worker to work, the schoolboy to application, the patient to the observation of the regulations. [....] He who is subjected to a field of visibility, and who knows it, assumes responsibility for the constraints of power; he makes them play spontaneously upon himself; he inscribes in himself the power relation in which he simultaneously plays both roles; he becomes the principle of his own subjection. (Foucault 1978: III.3)

Such an embodied practice of the disciplinary societies was reinforced in everyday life via what Foucault termed panopticism (Foucault 1980). He held that many people tend to conform to hegemonic norms in their everyday activities and relationships because of the interiorization of such norms via the presence of the gaze.

Deleuze argued that the technologies of disciplinary societies are being replaced with technology of a decidedly different type. Close-circuit television (CCTV) and computer monitoring software "scrutinize" our movements and interactions with others and with numerous electronic network interfaces (see also Lyon 1994). Other cases can be offered: the monitoring of computer use and key strokes in the workplace, the CCTV surveillance of traffic infractions, and the spy satellites which orbit the earth. Even Hollywood movies like "Enemy of the State" depict the use and abuse of technologies of control.

Such technologies can permit or deny entry through access points, as well as allow or disallow financial transactions at automated teller machines. Wrote Deleuze:

The conception of a control mechanism, giving the position of any element within an open environment at any given instant (whether animal in a reserve or human in a corporation, as with an electronic collar), is not necessarily one of science fiction. Felix Guattari has imagined a city where one would be able to leave one's apartment, one's street, one's neighborhood, 
thanks to one's (dividual) electronic card that raises a given barrier; but the card could just as easily be rejected on a given day or between certain hours; what counts is not the barrier but the computer that tracks each person's position-licit or illicit-and effects a universal modulation. (Deleuze 1992: section 3)

Technologies that open closed doors for us can just as easily keep them shut. Freedom and repression emanate from the same machines.

For Deleuze, the data gathered on us through the new technologies did not necessarily manifest our irreducible uniqueness. Rather, the very way that the data can be gathered about us and then used for and against us marks us as dividuals. Deleuze wrote (1992): “The numerical language of control is made of codes that mark access to information, or reject it. [....] Individuals have become 'dividuals' and masses [have become] samples, data, markets, or 'banks." For Deleuze, such technologies indicate that we as discrete selves are not in-divisible entities; on the contrary, we can be divided and subdivided endlessly. What starts as particular information about specific peopleour selves — can be separated from us and recombined in new ways outside of our control. Such "recombinations" are based on the criteria deemed salient by those with access to the information, be they government officials or corporate marketeers. We live now, Deleuze held, within societies of control.

How can we be deemed individual (in its irreducible and autonomous sense of agency) when we are divided into those with and without access. The very notion of individuality itself implies that actors are not only entitled to, but also capable of, effecting their will on the world. Access to resources-and the material social relations that are implicated therein - is thus the prerequisite for the practices and Western philosophical discourses that constitute the core an individual. Indeed, the early thinkers in the social contract tradition (like Thomas Hobbes and John Locke) considered in varying ways how the survival of embodied selves in a hypothetical state of nature faced dangers insofar as a government did not secure the rights of property deemed so basic to the existence of individuality in the first place.

\section{| Dividuality and our Reducible Selves}

Here, I provide a dialectical elaboration of Deleuze by focusing on two facets of "dividuality" that he did not develop in the "Postscript." First, the separation of physical selves from their representation as data offers both negative consequences as well as potentially positive uses for promoting social justice. Second, the individual selves in a mass-market society lose their aura of distinctiveness because the selves are able to be classified (and thereby manipulated) by the very data which are supposed to serve individual needs. Indeed, the manipulation of such information about individuals for marketing purposes highlights how the notion of "consumer sovereignty" is an overblown and contradictory term in an era of advanced globalization.

The processes of dividuality which operate via the technologies of control make distinctions that separate one from the many. But they also include the ways in which we ourselves are sub-divisible. That is, via the data collected on us, the technologies of control can separate who we are and what we are from our physical selves (see Poster 1990). The data become the representations of ourselves within the web of social relations; the data are the signifiers of our discrete preferences and habits. Borrowing from Laudon, such can be called our "data images" (Laudon 1986). Because I am not physically present I am thus reduced to my documented interests and behavior. Complex processes of self formation are thereby reified by a few formulae and data points in some electronic storage facility.

The separation of our selves from our representations illuminates another aspect of dividuality. As data, we are classifiable in diverse ways: we are sorted into different categories, and can be evaluated for different purposes. Are we potential customers or clients? (What have we purchased recently?) Are we a threat to national security? (What is our citizenship or visa status? Are we buying items that could build a bomb?) Our divisibility hence becomes the basis for our classifiability into salient, useful, and even profitable categories for the businesses and government agencies that manipulate the data.

Despite the rhetoric of having "it" our own way, companies typically do not make individual items that will be purchased by only one person. (In a capitalist world economy where is the profit in that?) Over the last several centuries the aura of discrete items has given way to the commonness of their mass production-not only as Walter Benjamin analyzed with regard to art work and mass media content (1969), but also in terms of our everyday items of consumption. For instance, the distinctiveness of a Sunday sit-down dinner made from scratch gives way to a 
"sumptuous buffet" as advertised at a local eatery. Choice, thus, tends to be limited to the possibility of selecting from among different styles, colors, and flavors.

A contradiction of modern society is manifested here: the irreducible uniqueness of self, so touted by Western value systems, is actually quite reducible to generalizable preferences (Frankfurt Institute for Social Research 1972; Horkheimer 1989). We are catalogued via a summation of our discrete desires and habits, and we make our consumer choices within a preestablished range of items and their available permutations. The niche targeting of commodities does not negate or lessen the influence of that preestablished set of commodities; indeed, it reinforces the mechanisms and techniques that dividuate us because we can be catalogued by past behaviors and purchases and then solicited in our niche with the "appropriate" marketing inducements to purchase those specific brands (Klein 2000).

As selves subjected to the technologies of control, we are all divisible entities. Nonetheless, the separation of our selves from our representations has a potentially positive dimension that might aid in social resistance. This is most clearly demonstrated in that realm where physicality is separated from its representations-cyberspace. Such a separation illuminates the particular characteristics of "high-tech" communications. In order to frame Deleuze's concept of dividuals as part of an emancipatory project for the 21th century we must theorize how resistance is possible. We should examine not only technology as such but also the specificity of digital technology and its cyberspaces.

\section{Technology and its Social Ramifications}

The arguments about the relationship of society and technology as well as the societal effects of technology are long and numerous. This section concentrates on the putative neutrality of technology, a perspective holding that technology is neither inherently good nor bad (see Pitt 2000). I will argue that technology is not neutral as to its effects on humans. Technology forces us to think, act, and live in ways distinctive to it. Whether those ways are deemed good or bad depend on our value systems and the answer to the question of who benefits and loses in economic and political terms. The insights of Benjamin and Adorno will provide the theoretical basis of this section.

As Martin Heidegger wrote in "The Question concerning Technology, modern technology enframes (gestellt) us in ways particular to its rhythms (Heidegger 1977). Modern technology challenges nature and humanity by revealing all to comprise a "standing reserve" (Bestand) which can be bent to human uses. For example, the landscape is disclosed as an open-pit mine, the earth as a repository of ores, and the ores as the source of steel and nuclear energy. Rivers are revealed as a source of hydro-electric power and mountains as challenges calling for the implements of technological progress to overcome the impediments of the peaks.

We do not have to agree with Heidegger's philosophy or his politics to understand the ways that technology can structure our existence. Other frameworks have also evaluated technology in terms of its negative repercussions. Herbert Marcuse, although once a student of Heidegger's, offered a Marxist analysis of technology that analyzes it in terms of an instrumentally rational capitalism. For Marcuse, technology ensnares us in a logic of the instrumental rationality of capitalism, forcing us to calculate according to efficiency and to limit our freedom to measurable choices (Marcuse 1978; but see Marcuse 1969 where he emphasized that oppression resulted, not from technology per se, but rather from how it is used to further capitalist profitability). But is the logic of technology always inherently negative or reactionary?

Some have argued that technology can be used in socially progressive ways. Walter Benjamin analyzed the political implications of the development of media technologies. He examined the effects of reproducibility on the social functioning of art in his famous essay, "The Work of Art in an Age of Mechanical Reproduction" (as the German essay, "Das Kunstwerk im Zeitalter seiner technischen Reproduzierbarkeit,”-technical reproducibilitywas translated [Benjamin 1969]). Art works such as paintings and sculpture possess an aura due to their uniqueness. Benjamin argued that when technologies like cameras, radio, and other forms of communication technology became more extensive in the 19th century, the aura of art declined or was eroded.

Aura, in Benjamin's analysis, functioned by a simultaneous presencing and distancing. The very presence of the art work bespoke its uniqueness, but by the same token such uniqueness created a distance between the art and its audience. This distance was not specifically or necessarily a distance defined in terms of measurable proximity. Rather, it was a social distance that separated the viewer from art because the art was embedded in a sanctified tradition and hierarchal social relations which framed the art as "great." 
Technical reproducibility, Benjamin held, removed the uniqueness of art because it could copy the original as many times as desired. In the physical presence of a reproduction the symbolically reverential distance between item and audience melted away. And with this dissolution of aura came the basis for a demystification of hierarchical and repressive ideologies as well as the increased possibilities for social transformation. Benjamin concluded that the decline of aura under conditions of technical reproducibility meant that radical movements could use art politically against the entrenched power structures.

Benjamin's loose affiliation with the Institute for Social Research did not mean that all members were in accord (Wiggershaus 1995). Not all of Benjamin's fellow theorists accepted his analysis of art in our capitalist technological age. For example, Theodor Adorno criticized Benjamin on at least two points (Adorno 1973, 1978b, 1981; also see, for example, Habermas 1983; Kaufman 2002).

First, Adorno disagreed that the decline of aura was revolutionary in itself. For Adorno some auratic art, or what he called autonomous art (like the sobering literature of Kafka and Baudelaire or the atonal music of Schoenberg), was able to preserve an emancipatory critique precisely because it distanced itself from mass-produced artworks. Indeed, for autonomous/auratic art such a distance meant that the art was not easily commodified and thereby might not become pablum for the masses. Emancipatory potential does not emerge from "mere" technical reproducibility. Rather, for Adorno, it is by identifying the values and visions of the artworks-especially by critically situated theorists - that we understand a liberatory project in terms of the critique offered by the unfulfilled promises "embedded" in the works themselves.

Second, Adorno disagreed with Benjamin on the implications of art directly used in the service of leftist political movements. Adorno argued that Benjamin offered an un-mediated notion of the technologies of reproducibility. In Adorno's view, Benjamin held that the new technologies and their content would lead to revolutionary action and progress. For Adorno, however, such technologies were particularly negative mediations between receivers and senders - that is, between the listeners/viewers and the capitalist firms and government officials. Those technologies functioned in terms of the instrumental rationality that served a late modern capitalist society (Jay 1984: 124). Specifically, the commodity form had become the dominant means by which to efficiently and effectively "produce" artworks and other cultural items. Profitability was emphasized in the production of cultural artifacts: exchange value (the worth of a thing calculated in monetary terms) was stressed rather than use value (the worth of a thing understood in terms of what a thing meant to the end-user).

Adorno's critiques of Benjamin fit within the treatment of what was he and co-author Max Horkheimer called the "culture industry" in Dialectic of Enlightenment (Horkheimer and Adorno 1973). That work argued for a reinterpretation of Western thought from the perspective of the increasing rationalization of society. The philosophers of the Enlightenment had hoped to use the power of human reason to release the shackles hitherto enchaining the human understanding of the world. Yet for Horkheimer and Adorno that philosophical project became problematic. The Enlightenment had unleashed a logic which justified subordinating nature so as to domesticate it. Yet such views and practices also contained the power to shackle society; the fascism of the 1930s and 1940s was the latest manifestation of that dialectical unfolding of enlightenment thought. Adorno and Horkheimer were concerned with fascist propaganda techniques and the Hollywood movie production system of that era, and how culture itself was produced utilizing those same techniques (Schmidt 1998; also see Giovacchini 1998). With the concept of the culture industry Horkheimer and Adorno interrogated popular culture-how its products like movies and advertising were created and distributed as well as how its negative consequences for society and individuals arose from the extension of the commodity form to cultural works produced and distributed for sale.

Negative consequences resulted from the culture industry (Adorno 1975; Horkheimer and Adorno 1973): (a) the commodity form led to a standardization of products, pseudo-individuation wherein supposed originality actually fits within preestablished patterns, mythic repetition of certain simplistic movie themes, and the generation of false needs (e.g., halitosis would seem a problem on par with environmental concerns); (b) the content of cultural products tended to use motifs and story lines that depicted false harmonizing (e.g., "happily ever after" endings and Norman Rockwell-like imagery); and (c) the consumption of a cultural product reinforced passivity and the status quo.

In the grip of the culture industry, the revolutionary spirit of a class-conscious proletariat was all but moribund. For Adorno, the instrumental rationality of late capitalism had prevailed — a conclusion that he continued to maintain in his later writing (e.g., Adorno 1975). As he wrote in Minima Moralia, "The saving principle [for liberating humanity] is now preserved in its antithesis alone.” (Adorno 1974: Aphorism Nr. 97). Modern technology for Adorno engulfed human hope and freedom. 
To grasp the possibilities of resistance against such high-tech dungeons and their attendant dividuals will require a different theoretical basis. Delineating that theoretical basis also will accentuate the potential of human agency that is embodied in our selves.

\section{Theorizing the Digital Technology of the Internet}

Later theorists have analyzed the question and consequences of modern technology differently than Adorno. They supplement Benjamin's insights and allow us to glimpse the potentials for social resistance which arise from Deleuzean dividuality. This section sets forth Hans Magnus Enzensberger's theory of technologically based resistance, and complements his thought with that of Andrew Feenberg and Mark Poster. The section then extends such theories to the Internet and the digitality of its cyberspaces.

Enzensberger set forth his argument in "Constituents of a Theory of the Media" (1982a). Enzensberger framed the technologies of reproducibility (including communication technologies like radio, video cameras, etc.) in terms of their mediating potential, a potential that focused on their bi-directional capabilities. Communication technologies are two-way: a receiver, either device or person, could become a sender. Indeed, technology as mediation/means could be turned against the power structures as part of a broader counter-hegemonic strategy.

Enzensberger thereby implicitly criticized the presupposition of Adorno's critique of Benjamin: namely, that the technologies of reproducibility operate chiefly as a one-way means of communication. Because of the two-way aspect of technology, Enzensberger did not agree that an audience necessarily would be passive receivers. In his essay "The Industrialization of the Mind," he suggested that new complex technologies require intelligent people who retain their thinking faculties_-faculties that might be turned against the hegemonic power structures (Enzensberger 1982b).

Technology, for Enzensberger, was not an end in itself, but only a possibly useful mediating device towards the ends sought by social movements. Such an argument did not theorize a way to supplant the instrumental rationality of modern technology; rather, it held that technology and its rationality could be wielded against the dominant order by the same groups deemed by Adorno to be trapped within a(n almost) totally administered society.

Enzensberger offered a dialectical theory of the new forms of communication, a theory which analyzed the immanent potential of technology for pursuing social justice. Technology thus did not generate only injustice and oppression. Feenberg's Questioning Technology (1999) and Poster's What's the Matter with the Internet? (2001b) and The Second Media Age (1995) provide further interrogations of technology.

Feenberg, like Enzensberger, also argued that technology does not inherently tend towards one necessary use or consequence. As Feenberg argued, technology is not an isolated phenomenon; it exists in a "use-context" within which and in terms of which it is evaluated. In the domains where technology reigns as cutting-edge (specifically, in government and business), efficiency dominates. Efficiency, from the perspective of business, is the criterion that allows a company to evaluate technology: does a particular device help the business generate more profits? From the perspective of government, does a certain technology achieve the desired result most efficiently? Yet in our everyday life a different criterion is used, namely, meaningfulness. What is meaningful to us at home, for example, differs from what is meaningful at work. Hence, technology is evaluated within contexts which establish particular "horizons" of meaning. Here Feenberg employs the notion of signification, although he does not seem to consider that technology is indefinitely open with regard to what it can mean. Nonetheless, the meaning of technology exceeds the instrumental rationality of the technocrats in government and business. Feenberg illustrated his argument with reference to a French telephone-like communication system which was intended for accessing government databases. Instead, the users found other things to do, such as communicate with each other. Because technology derives some of its meaning from actual use by us in everyday life Feenberg theorizes that alternate uses of technology might also prefigure the possibility for alternate social systems.

Feenberg did not detail the specific case of digital technology or cyberspace. His was a more general theory of technology seeking to find commonality among the various forms of technology and the various forms of social struggle that currently exist. Identity groups, which have supplanted numerically work-based organizations such as unions might find common ground in struggles over the uses of technology which pervade every aspect of social life. A "democratic rationalization" of technology, as he termed it, might vanquish the technological rationalization that historically has prevailed. 
Poster quite directly tackled the Internet by way of theorizing the relationship of human identity to technology. He worked explicitly in the tradition which holds that changes in communication technology bring about changes in human subjectivity, specifically changes in the sources for the constitution of identity. In figuring out who we are, we can draw upon many sources from other communities in other places. Crucial to this argument is the idea that our identity is itself a signification system, as indicated in a previous section, is "radically open" to new configurations. Digital technology is integral to such reconfiguring because it permits the morphing of its products in ways that alter the original. In Poster's analysis, there is no one-way use of digital technology. Rejected here are Adorno and others who theorized the domination of technology and its instrumental rationality over humans and their subjectivity. Rather, technology is held by Poster to be "underdetermined"-e.g, its consumption and use were not dictated by the technological form or its norms of technical efficiency. Humans can use it in ways different than was intended. Here Poster's conclusion about the progressive use of technology converges with Feenberg's. Alternate uses spell alternate meanings and values, which in turn potentially can spell alternate social futures.

For my purposes, both Feenberg and Poster, albeit in different ways, indicate that technology neither yields deterministic results nor totally dominates us. Human agency in its capacity for action and meaningful production of the world emerges from within, and in opposition to, the technological snares of modernity. Let us now apply such insights to the digital technology of the Internet.

The progressive possibilities that emerge from the Internet lie in its heightened potential for interactivity between senders and receivers. Such interactivity is facilitated via the digitality of the Internet and the multi-directionality of its cyberspaces. Digitality translates everything to, or everything is reduced to, bits of data that are communicated in an underlying binary language. The uniqueness of a thing per se-the physical basis for Benjamin's notion of aura - if not already eroded by mechanical-reproductive technologies is obliterated by digital technologies. Indeed, with digital text or graphics there is no original in the sense of a unique thing. A file may be initially created on one's home computer, but "copying" it to other storage media like diskettes does not generate copies in the older sense of (near perfect) facsimiles. Rather, the back-ups are perfectly identical as far as appearances and uses are concernedso much so that we could not distinguish them from the initial one created. There is no need to even consider which file was the initial one created. This perfect (digital) identity could not be claimed for text or graphics reproduced via, for example, dittograph devices, photocopiers, or fax machines.

The Internet as a network of networks facilitates the bi-, even multi-, directionality of communication. The multi-directionality of Internet has been characterized in terms of Deleuze and Guattari's idea of the rhizome (Froehling 1997; Hamman 1996; Stivale 1994; Warf and Grimes 1997; Wray 1998). The concept of "rhizome" is intended to theorize the multifarious assemblages of thought and action that develop in opposition to the hierarchical (or arborescent) structures of the state and capital (Deleuze and Guattari 1987). In hierarchies, decisions and authority permeate pre-established paths, subordinating the many in the interests of an elite few. Rhizomes, however, epitomize not only fluidity (in opposition to rigidity), but also the mutuality and egalitarianism of the myriad Net interconnections. In a rhizome, paths continuously branch in all directions. If one path is stifled, then others are used or created in order to bypass the obsolete or obstructed ones. The rhizomorphic dimension of the Internet conveys some sense of the Net's anarchic, acentered, and mutating aspects.

Ultimately, then, the question concerning technology is more a question about the conditions under which technology can be wielded for progressive ends. Such conditions are important to study. Society and its human agents are molded and melded by technology, but also can potentially transform the technology that humans created. Such a dialectical assessment posits technology as a multi-directional mediation. Overcoming modern technology seems out of the question - perhaps this is why pessimism loomed over the later works of many of the Frankfurt School theorists. Yet resistance is not necessarily futile because dividuality offers the potential for struggle.

\section{| Dividuals and Cyber-Resistance}

Cyberspace is not a "real" place in the sense of a location where we physically meet. "There's no there, there" in cyberspace (Gibson 1988: 40). Cyberspace is thus a construct which allows us to make sense of the interactions of people via computer networks. To cite one of Gibson's more problematic descriptions (cf. Kellner 1995), cyberspace is "a consensual hallucination" (Gibson 1984: 51). Yet, as this section will indicate, the potential for cyber-resistance against technological domination rests on the intentional, collective interactivity implied by the adjective "consensual" 
(see Feenberg 1999; Kellner 1997). I will briefly outline the history of communication technology, with special reference to disembodiment, for it is the disembodiment facilitated by digital communication technologies that permits of cyber-actions by dividuals. Next, the positive benefits of dividual action in cyberspace will be "posted." Finally, there follows a short list of groups using the Internet to establish cyberspaces that promote their social and political visions.

Historically, the development of communication technologies has increasingly enabled us to project our thoughts and intentions at a distance. Earlier technologies, like the telegraph, telephone, and two-way radio, have allowed us to extend our "presence" into areas where we are physically absent, i.e., disembodied (Postman 1993; Thrift 1996; Thompson 1995). The disembodiment of cyberspace heralds new levels of human interactivity and instantaneity, all facilitated by the highly advanced communications networks of the Internet (Poster 2001a). Television and radio certainly have allowed some to broadcast their views, and to excite, incite and otherwise mobilize others towards some political end. The older broadcast technologies have "reached" into our homes. Nonetheless, the Internet combines radio and TV elements in a way that permits relatively easier access to more people than the older technologies hitherto have done.

Disembodiment has implications for the traditional bases for political actions. Politics has historically involved co-presence: the self's intentionally political acts and its body occur in one place (Giddens 1984). Such co-presence has hitherto delimited political actions, often in terms of territorial units: I can only be in one spot at one time in order to effect some action, whether voting, attending political rallies, or mobilizing grass-roots support on some issue. However, cyberspace transfixes political boundaries and social spaces, and thereby permits an extension of the bodily scope of political actions; in effect, the physical body is "removed" in cyberspace from the intentional actions of the subjectivity which coexists with the body. Nowadays we are able to perform many political acts as volitional agents without having to dwell physically in social places. And "there" lies the potential for dividuality to facilitate progressive social change.

The disembodiment of the Internet and its cyberspaces has implications for our selves and our capacity for resistance and social injustice and political oppression. I will outline five sets of cases to illustrate this point. First, political actions can be initiated beyond our physical presence. In the mid 1990s the Zapatista uprising received global support and even assistance in the form of e-mails sent to the Mexican government (Cleaver 1998; Kowal 2002; Ronfeldt et al. 1998). We can now be Zapatistas if we want, because we do not have to be co-present in the jungles of Chiapas. We can show our solidarity by directing our political will into Mexico while our actual body resides elsewhere.

Second, such forms of political activism push the limits on the use of the Internet and other forms of computer networks. Many however have envisioned computer networks to make the provision of government services and functions more efficient within national or subnational boundaries. Government services are provided online so as to avoid waiting in line (e.g., surf to www.firstgov.gov for the official U.S. government homepage). Also, electronic voting has been attempted in some localities around the world, such as on governmental issues in Switzerland and England (Associated Press 2003; Peterson 2002). In the U.S., a few states have used remote electronic voting during primary elections (Arizona) and for military personnel to cast absentee voting (Florida and Virginia) (see Madigan 2002).

Third, new political communities can be created over the Internet. We can find or even fashion a commonality of interest that crosses political borders and thereby helps to ally our selves with the "Other" selves in different parts of the world (Warf and Grimes 1997). Communities of mutually held or cooperatively created ideas and interests can be formed around, for example, environmental issues, opposition to war, or even online role-playing games.

Fourth, disembodied politics permits citizens to create their own identities, thereby promoting equality beyond the possibly oppressive signifiers of race, gender, class, sexuality, differential ability (Poster 2001b). For example, in chat rooms we can wrap our selves in new and variegated personas (Turkle 1996). We can "morph" our selvesspecifically, our disincarnated avatars - in a rainbow of ways that differ from the body at the computer terminal.

Fifth, cyberspace is a "world" wherein dominant economic and social values are fought against and even transgressed, albeit not always for socially progressive ends. While groups can organize and agitate against the status quo, like anti-globalization protestors and anti-war activists, there are also other activities afoot in cyberspace. Illegalities can be found, from the hacking of web sites and commercial and governmental databases to the illegal distribution and downloading of pirated movies, software, and music. Cyberspace thus permits what de Certeau called the "tactics" of everyday struggle, which are deployed against the "strategies" of control wielded by corporate 
and governmental institutions (de Certeau 1984). A tactic like "bricolage" would use some thing found or discarded within the dominant social order for other than its intended purposes. The tactic of "la perruque" spoke to the ways in which official rules were broken from with the social institutions themselves, such as when employees abuse company time for their own personal ends. Although de Certeau studied the physical realm, activities in cyberspace witness his insights into human behaviors, embodied or otherwise.

Researchers have studied a multitude of cases in support of cyberpolitics and the uses of the Internet just cited. The Internet permits groups to express concerns, even protest, and to mobilize across political boundaries, both subnationally and transnationally (Ayres 1999; Bleiker 2000; Kellner 1997). Human rights organizations, political parties, interest groups, and anti-government organizations offer ready examples. Human rights groups, like Amnesty International (www.amnesty.org) and Human Rights Watch (www.hrw.org), use the Internet to distribute their analyses of violations. Such actions contribute to a cyberspatial sphere for the pursuit of rights that transcend (sub)territorial units.

Of course, groups across the spectrum use the Internet to communicate with members, mobilize support, articulate their views, raise money, and so forth. In the United States, the Republican National Committee extols the virtue of the Internet in political campaigning (P. Harrison 2000; Republican National Committee 2002). In addition, hate groups use cyberspace for mobilizing and fund-raising purposes. Examples range from the Ku Klux Klan and neo-Nazi groups to racist skinhead and Christian Identity groups (Anti-Defamation League 2004).

Various anti-government groups have used the Web. As indicated above, the Zapatista insurgency in Mexico during the 1990s is an exemplary case. Other anti-government groups have presented their positions via the Internet, such as Peru's Shining Path movement, Sendero Luminoso (Committee to Support the Revolution in Peru, www. csrp.org), and also Peru's Movimiento Revolucionario Tupac Amaru, or MRTA (Dartnell 2001).

How effective the Internet is for achieving political objectives depends on a number of factors, all of which are beyond the scope of the present work. In this section, the directly political uses of the Net were stressed as a potential way that dividuality provided the basis for resistance against the processes that limit humans in the first instance. The separation of the incarnated self from its infinitely re(pro)ducible representation-so problematic and limiting for us within an embodied society-becomes in cyberspace a new modality for potential rage against the technologies of control.

\section{Some Criticisms of the Internet's Emancipatory Potential}

There are several traditions of leftist thought, including post-Marxism and poststructuralism, that would raise objections to an analysis of the emancipatory potentials of the Internet. In this section I will address two well known thinkers, Jean Baudrillard and Paul Virilio, who could inspire criticisms of this paper's project.

Jean Baudrillard's idea of simulation strikes at the very heart of the possibility of the progressive use of cyberactivism. For Baudrillard, simulation has come to characterize the mode of social production and reproduction of the real. Before Ferdinand de Saussure, it was assumed that a sign of some thing, like a name or image, actually refers to that thing in the real world. Baudrillard argues that our present postmodern condition is hyperreal, where signs refer to other signs in vast reticulated systems of self-referentiality. Baudrillard called this condition "simulation" (Baudrillard 1988: 145). The sign systems created via simulation are the simulacra: depictions of reality for which there is no original. Theme parks, like Disney World, offer cogent examples of simulacra depicting a fairy-tale world. The use of allusions in advertisements and movies to previous cultural products illustrates the seemingly endless plays of signifiers which do not represent real things.

Extending Baudrillard's ideas, cyberspace is a world of simulation, where the signs connecting us to other people or things in that domain no longer have any connection to reality. You can be "other" than you are in the physical world because the signifiers of your identity — the online gaming avatars, the screen names, etc. — do not necessarily match your physicality. Cyberspace, for Baudrillard, is a realm of shimmering surfaces where the signifiers float and can be joined to virtually any signified. As a consequence, signifiers ultimately mean nothing in particular (Jarvis 1998; Kroker and Cook 1986: 176-7; Nunes 1995). As Baudrillard wrote:

$[\mathrm{T}]$ he age of simulation thus begins with a liquidation of all referentials-worse: by their artificial resurrection in systems of signs, a more ductile material than meaning, in that it lends itself to all systems of equivalence, all binary oppositions and all 
combinatory algebra. It is no longer a question of imitation, nor of reduplication, nor even of parody. It is rather a question of substituting signs of the real for the real itself.... Never again will the real have to be produced-this is the vital function of the model in a system of death, or rather of anticipated resurrection which no longer leaves any chance even in the event of death. A hyperreal henceforth sheltered from the imaginary, and from any distinction between the real and the imaginary, leaving room only for the orbital recurrence of models and the simulated generation of difference. (Baudrillard 1988: 167).

In that passage, we see that the simulation processes that create the simulacra do not refer to imitation (see Raulet 1991). Imitation would still posit a reality to which signs could refer. Rather, simulation is productionthe production of increasingly self-referential sign systems that are reality or, to use Baudrillard's term, the real is hyperreal. In such a hyperreal world cyber-activism, even cyber-resistance, is useless: the loss of the capacity to generate truth (or even TRUTH) spells the futility of political actions seeking to create a more just world.

There are various cogent criticisms of Baudrillard's concepts of hyperreality and simulation (e.g., Best and Kellner 1991; Bleiker 2000; King 1998; and Luke 1991). Kellner, for example, points to Baudrillard's analytical stress on simulation as form rather than the apparatus of the media technologies that are integral to Baudrillardian simulation (Kellner n.d.). Hence, one avenue for an immanent critique of Baudrillard is to theorize the role of technology in terms of its necessary and implied social relationships. For Baudrillard, production in a Marxian sense has been superceded and replaced by the interminable reproduction of signifiers. But we can ask Baudrillard: what about the technology through which the signs are communicated and distributed? Such technology is itself evidence of an obdurate physicality and it marks the social materiality that Baudrillard argued had been supplanted by reproduction (see Luke 1991). Technology as mediation bears the social reality that characterizes its basis in capitalist production processes, including worker loss of control over production decisions and exploitative wage labor conditions (see Downey 2004).

It is precisely the technological mediations, and the humans embodied in social relationships, that lie at the core of the Internet's potential for facilitating the struggles for social justice. And just as certainly those interconnections, as well as the implications of disembodiment in cyberspace, have been criticized. Paul Virilio offers a good example of one such critic.

Paul Virilio has studied the ways in which advanced communication technologies have increased the speed of human interaction (e.g., Virilio 1994; Virilio 1995; Virilio 1996). The accelerated speed of cyberspace's synchronous communications not only erases distance (to the applause of cyber-politics's proponents), but also creates instantaneity. In Virilio's words, cyberspace allows for "instantaneous telepresence" (Virilio 1997: 10-11). This has changed the world, Virilio argued, because we now can act at a distance (i.e., "tele-action," or "action-at-a-distance" [Virilio 1996]).

For Virilio, however, such telepresence and any of its advantages must be understood in terms of its serious human costs.

Action-at-a-distance is a phenomenon of absolute disorientation. We now have the possibility of seeing at a distance, of hearing at a distance, and of acting at a distance, and this results in a process of de-localization, of the unrooting of the being. 'To be' used to mean to be somewhere, to be situated, in the here and now, but the 'situation' of the essence of being is undermined by the instantaneity, the immediacy, and the ubiquity which are characteristic of our epoch. (Virilio 1996)

For Virilio, the speed and placelessness of cyberspace disorients humans. The bodily immediacy that helps to confer meaning on places is lost in the cyberspaces of the Net, a situation made all the worse in an accelerating world.

For Virilio, there was another negative dimension of our interwoven and high-tech world. A global accident was possible, Virilio argued, wherein our very technological interconnectedness would cause a problem in one area to ramify across the globe (Virilio 1994; Virilio 1996). Had the so-called Y2K Bug actually happened as some anticipated on 1 January 2000, we would have witnessed just such a global accident.

Virilio has indicated there is something of use in information society, especially in developing or fostering a degree of commonality (Virilio n.d.). Nonetheless, the general trend of his work laments the increasing diminution of face-to-face interactions among people (Armitage 2000). As a consequence, Virilio's work does not enable us to theorize a positive set of strategies and tactics for cyber-activism (Kellner 1999). Such would require us to understand the capacity for human agency to grapple with, and maybe to ameliorate, the often oppressive effects of the interconnected high-tech world. This in turn would require a different philosophical basis. As the overall theme of this paper has indicated, the key to understanding the progressive opportunities of cyberspace is to understand the relationship of human agency and technology. Human agency is constituted and reconstituted by society and its 
technology, but also is vital in the creation of that technology in the first instance — and that dialectical relationship is the fundamental basis for hope. Such a relationship is at odds with theoretical positions reducing humans to unconscious animals, atoms colliding in space, or automatons agog at technological forces swirling beyond their control.

High-tech communications make for dangers and problems, as both Baudrillard and Virilio have well illustrated. Our potential to change society via technology nevertheless offers considerable hope. But our human agency is not boundless, for there are material (or structural) limitations on our activities. The next section outlines several dimensions of such constraints.

\section{The Materiality of Cyberspace: Caveats for Cyber-Resistance}

I do not wish to sound overly optimistic; there are limitations to the political effectiveness of a self disincarnated from its physical body. While technology removes the physicality of our embodied selves from cyberpolitics, cyberspace has not necessarily removed the embodied materiality on which the Internet is based. Indeed, materiality in the form of, for example, computer hardware as well as communication equipment and satellites provides the necessary conditions for the possibility of cyberspace. All Net users-whether casual Web surfers, e-commerce shoppers, dedicated social activists, or the "console cowboys" of cyber-fiction (Gibson 1984; also read Vinge's "True Names" originally published in 1981 [Vinge and Frenkel 1999]) —require the materiality of hardware to attain the incorporeal domain of cyberspace.

Materiality entails more than the mere physicality of things. Social relationships of production, distribution, and consumption mediate those "things" (e.g., see Adorno 1981; Horkheimer 1989). Such relationships frame our actions in terms of opportunities and constraints as well as in terms of values and what "counts" as valuable. But, as many critics on the left argue, the constraints and opportunities are not equally distributed. Thereby, schisms are generated between the rich and poor, those with capital and those with little else but their labor power to sell. Moreover, what things and actions are counted as valuable often have no necessary connection to their intrinsic worth for societal survival. School teachers and garbage collectors as well as surgeons and (arguably) entertainment celebrities all perform societally useful roles. Yet the latter group tends to be paid vastly more than the former. Whatever the market will bear does not necessarily lead to just outcomes. Capitalist relations hence yield oppression, alienation, and exploitation.

In the same measure, the Internet can be examined in terms of its materiality. Indeed, the components of the Internet do not spring fully formed from the brows of software programmers, computer engineers, and dot-com entrepreneurs - no autonomous technology here. The Net's components are embedded in capitalist relations of production. The telephone and fiber optic lines, the satellite systems, the routers that coordinate the packets of data whirling at high velocity, and the computers on our desktops are produced by flesh-and-blood people in specific locations under the unequal conditions of wage labor (Downey 2004). Such material relationships also hold true for the software - and the programmers, of course - that permit the different components to work together to achieve communication. Moreover, the impetus to knit places together via advanced technology is profit-driven. Yet places without a market demand might not be served, even though fellow human beings live in those "other" places.

The capitalist relations mediating the creation and use of the Internet are not without their political dimensions. The kernel of what became the Internet was itself initially the creation of U.S. government military policy in the grip of the Cold War (Louw 2001; Murphy 2002). Hence, materiality is not simply economic. It is best understood as a political-economic ensemble of social relations, each affecting the other in mutually reinforcing ways. Some actors are structurally and systemically selected over others in terms of their supportive roles in production, circulation, and consumption (e.g., Offe 1974). Those who do not possess financial or political "capital" often are effectively hindered, even if not legally or coercively forbidden, from exerting meaningful influence over public policy. This holds for Internet policy as it does for other issue areas. The governmental arenas may be formally open to all citizens in a capitalist liberal democracy, but not all voices carry equal weight or are equitably served.

What follows is a short list of the ways in which material relations (in the broadest, interrelated sense) not only constrain our actions in the corporeal world, but also persist in the disembodied realm of cyberspace. I will sketch five constraints on the potential of dividuality to overcome the oppressive relations of control.

The first material constraint highlights the hegemony of capitalist relations and norms. Despite the emancipatory 
potential of cyberspace's open-source ethic (see, e.g., Barbrook 2000 on "cyber-communism"), market-oriented ideologies remain a dominant way to understand how to utilize the Internet (Hirschkop 1996). Profitability is the touchstone for much of what is produced for distribution via the Net (Louw 2001).

The second material constraint involves inequality. There are inequalities associated with the Internet which affect what is consumed and how things are distributed. This is most clearly manifested in the "digital divide" (Norris 2001). The "digital divide" describes the gap between those who have and those who do not have (adequate) computers, the appropriate knowledge, and money for Internet access. The divide unequally determines who can access the Internet and participate cyber-spatially (Dickard 2002; D. Jackson 2002).

The third material constraint entails the nexus between liberal-democratic governments and capitalism. Corporate and governmental policies can limit the potential for digital technologies to be used in ways that emancipate us from injustice and inequality. There are uses made of digital technology that threaten the economic status quo. For example, peer-to-peer file sharing can be financially damaging, as the record industry has argued. But it is even more problematic in that peer-to-peer networks promote the view that information and intellectual property should be free. To thwart just such a notion from gripping more than a small percentage of computer users, the Record Industry Association of America (RIAA) has sought court-ordered injunctions against the Web sites involved and vendors of the facilitating software. The RIAA is also pursuing legal action against hundreds of alleged file-sharers of copyrighted songs (RIAA 2004). Hence, liberal-democratic governments tend to cooperate with corporations due to the very real-i.e., material-interests that such governments have in maintaining a capitalist economy.

The fourth material constraint involves the issue of government surveillance. Access to the Internet can be denied or monitored via government agencies. Such governmental control affects not only how things are distributed in cyberspace but also whether we can utilize them in the first instance. Various governments in non-democratic countries may not target specific people but rather prohibit access via control of the nodal points connecting the various national Internet Service Providers to the Net itself (Kalathil and Boas 2003). Many governments, periodically including liberal-democratic ones, routinely surveil the contents of cyberspace and those who access it through the Internet gateways (Bodeen 2002).

The fifth material constraint points to limits on the possible success of any cyberspatial "consciousness raising." The materiality of cyberspace also affects consciousness and the identity of our selves. Consciousness is not necessarily transformed by the digital technology of the Net, McLuhan notwithstanding (1964). Human prejudices are rooted in social, hence material, relationships. How people interact and communicate with others, even in cyberspace, thus will remain socially embedded (Crawford 2002). Prejudices are not necessarily transformed in cyberspatial communications. Indeed, various forms of prejudice and hatred have been expressed in cyberspace (Fernandez 1999; Kendall 1998; Postmes et al. 1998).

Cyberspace and its preconditions for disembodiment hence have a concrete material base. Cyberspace is often understood to be an analog to the mind. The materiality of cyberspace, however, highlights the embodiment of our consciousness because of the biological locations and the social situations that our selves inhabit whenever we sit at the keyboards and mouse pads. The cyber-conscious of the self is biologically located in space; it dwells within a body, which itself exists within social structures (Lefebvre 1991; Rich 1986). Those social structures involve the ways in which we are constituted as human - who we are in terms of race, class, gender, age, and differential ability. This in turn expresses our life chances, including our access to resources, our exposure to the dominant values in the business and political worlds, and so forth. Cyberspace, when conceived as essentially ethereal and disembodied, is a problematic concept.

Material injustices will continue to constrain our opportunities for struggle. Cyber-resistance is useful, even invaluable; but resistance ultimately retains its embodied component. Thus, by virtue of the materiality involved, incorporeality can supplement, but not supplant, political action in particular places. Despite the world-wide support for the Zapatistas, it was they who put their selves — their mind and body, heart, spirit, and personal identity - in actual danger (see Hellman 1999; for a critique of Hellman, see Cleaver 2000). Activism will still require selves in all of their embodied capacities to resist more thoroughly the repressive relationships of society.

\section{A Future for Our Selves}

Despite the limitations of cyberpolitics, I wish to end with measured optimism about the future of selves. Computer networks and other technologies may translate us into dividuals by classifying and reducing us to formulaic 
and lifeless representations of our human potential. By means of our technological reproducibility we are digitally reduced to data streams which do not fully mirror our uniqueness and worth as individuals. Such a consequence of digitality argues against the pervasive Western ideologies of individuality. As indicated previously, what we need to effect our individual natures can be denied us, and thereby reveals the inherent tension within capitalist digitality.

What constitutes us as selves (in body and mind) also influences us. Yet we as selves are not reduced to such influences or prejudices. As dividuals, we may be reduced to data representations, but that does not reduce the capacity of our selves as agents because data do not attack our selves' potential for alternative thought and progressive action, only our expression of it in the here and now. Moreover, our body anchors our spatio-temporal praxis, not in its physicality (not as an irreducible presence), but rather by its implication and constitution within social relationships. And bodies conjoined with minds speak of the possibilities of social progress. Herein lies theoretical hope and optimism: ultimately, who we are — and who we can become — transcends our data representations at any one point in time and space.

Resistance to oppression does not arise automatically from the "proper" conjunction of social forces or from the availability of technological means. Resistance must be organized politically "on the ground." Nonetheless, theorizing the conditions for the possibility of resistance is necessary. It requires analysis of the material structure of society, a structure which constrains both our praxis and our cyber-praxis. As indicated above, we do not escape the materiality of our embodied social existence, even in the decorporealized realm of cyberspace. Resource inequalities and hegemonic norms, both generated by exploitative production relationships, will place limits on who can act and on the reasons for which they might act.

Nonetheless, the technologies in Deleuze's concept of the societies of control also hold the possibility for progressive social change. By reproducing our selves as digital representations in places where we are not physically located, we enhance our capabilities to act and interact in other places. The technologies of control hence might allow for our reproducibility elsewhere, and thereby might facilitate the possible creation of commonality and transborder alliances. Resistance in the 21st century is also digital resistance. Cyberspace offers us dividuals "an-Other" terrain for social struggle.

With such claims I theorize in the tradition of thinkers like Benjamin, Enzensberger, Feenberg, and Poster, while also eschewing technological pessimism. In a similar spirit Deleuze wrote: "There is no need to fear or hope, but only to look for new weapons" (Deleuze 1992). And, I might add, perhaps we can start with the tools at hand.

\section{References}

Adorno, Theodor W. 1973. "Letters to Walter Benjamin." Translated by Harry Zohn. New Left Review 81: 46-80.

-.-. 1974 [1951]. Minima Moralia: Reflections from Damaged Life. Translated by E. F. N. Jephcott. London: Verso.

---. 1975 [1967]. “Culture Industry Reconsidered.” New German Critique 6: 12-19.

-..-. 1978a [1960]. “Culture and Administration.” Telos 37: 93-111.

---. 1978b. "On the Fetish-Character of Music and the Regression of Listening." Pp. 270-299 in The Essential Frankfurt School Reader, edited by Andrew Arato and Eike Gebhardt. NY: Urizen Books.

-.-. 1981 [1967]. Prisms. Translated by Samuel Weber and Shierry Weber. Cambridge: MA: MIT Press.

---. 1981. "A Portrait of Walter Benjamin." Pp. 227-241 in Theodor W. Adorno, Prisms, translated by Samuel Weber and Shierry Weber. Cambridge: MA: MIT Press.

Althusser, Louis. 1971. "Ideology and Ideological State Apparatuses (Notes towards an Investigation).” Pp. 127-186 in L. Althusser, Lenin and Philosophy and Other Essays, translated by Ben Brewster. London: New Left Books.
Amnesty International. 2002. "Amnesty International's Concerns Regarding Post September 11 Detentions in the USA." March 14, 2002. AI-index: AMR 51/044/2002.

Anti-Defamation League. 2004. "ADL Extremism Main Page." http://www.adl.org/extremism/default.asp\#inet_hate. Accessed July 12, 2004.

Antonio, Robert J. 1981. "Immanent Critique as the Core of Critical Theory: Its Origins and Developments in Hegel, Marx and Contemporary Thought." British Journal of Sociology 32: 330-345.

Armitage, John. 2000. "Beyond Postmodernism? Paul Virilio's Hypermodern Cultural Theory." www.ctheory.net/text file?pick=133. Accessed July 11, 2004.

Associated Press. 2003. "Swiss Village Holds First Internet Vote." January 19. http://apnews1.iwon.com/article/20030119/ D7OLFRPG1.htm. Accessed January 19, 2003.

Ayres, Jeffrey M. 1999. "From the Streets to the Internet: The Cyber-Diffusion of Contention." Annals of the American Academy of Political \& Social Science 566: 132-143.

Barbrook, Richard. 2000. "Cyber-Communism: How the Americans Are Superseding Capitalism in Cyberspace." Science as Culture 9: 5-40. 
Barnes, Barry. 2001. "The Macro/Micro Problem and the Problem of Structure and Agency." Pp. 339-352 in Handbook of Social Theory, edited by George Ritzer and Barry Smart. London: SAGE Publications.

Baudrillard, Jean. 1988. "Simulacra and Simulations (Excerpt)." Pp. 166-184 in Jean Baudrillard, Selected Writings, edited by Mark Poster. Stanford, CA: Stanford University Press.

Beauvoir, Simone de. 1972 [1953]. The Second Sex. Translated by H. Parshley. Harmondsworth: Penguin.

Best, Steven and Douglas Kellner. 1991. Postmodern Theory: Critical Interrogations. NY: Guilford Press.

Benjamin, Walter. 1969. "The Work of Art in an Age of Mechanical Reproduction.” In W. Benjamin, Illuminations, edited by Hannah Arendt; translated by Harry Zohn. NY: Schoken Books.

Bleiker, Roland. 2000. "The Changing Space and Speed of Dissident Politics." Social Alternatives 19: 9-15.

Bodeen, Christopher. 2002. "China Blocks Google Search Engine." Associated Press News Service. September 3. http:// apnews1.iwon.com/article/20020904/D7LQNS3G0.html. Accessed September 3, 2002.

Bowman, Lisa M. 2003. "U.S. Ushers in E-government." CNET News.com. April 18. http://news.com.com/2100-1028997496.html. Accessed April 28, 2003.

Chang, Nancy. 2001. “The USA PATRIOT Act: What's So Patriotic About Trampling on the Bill of Rights?" Center for Constitutional Rights (New York City). November 2001. http://www.ccr-ny.org/whatsnew/usa_patriot_act.asp. Accessed January 30, 2002.

Cleaver, Harry. 1998. "The Zapatistas and the Electronic Fabric of Struggle." www.eco.utexas.edu/Homepages/Faculty/Cleaver/ zaps.html. Accessed August 25, 2002.

----. 2000. "The Virtual and Real Chiapas Support Network: A Review and Critique of Judith Adler Hellman's 'Real and Virtual Chiapas [...]., Socialist Register, 2000.” www.eco.utexas. edu/Homepages/Faculty/Cleaver/antihellman.html. Accessed February 12, 2003.

Cole, David and James X. Dempsey. 2002. Terrorism and the Constitution. NY: The New Press.

Crawford, Alice. 2002. "The Myth of the Unmarked Net Speaker." Pp. 89-104 in Critical Perspectives on the Internet, edited by Greg Elmer. Lanham, MD: Rowman \& Littlefield.

Dartnell, Michael. 2001. "Insurgency Online: http://burn.ucsd. edu/ ats/mrta.htm.” http://www.yorku.ca/dartnell/mrta. html. Accessed September 2, 2002.

de Certeau, Michel. 1984. The Practice of Everyday Life. Translated by Steven Rendall. Berkeley: University of California Press.

Deleuze, Gilles. 1992. "Postscript on the Societies of Control." October, 59: 3-7. Available online: http://www.spunk.org/ texts/misc/sp000962.txt. Accessed August 25, 2002.

Deleuze, Gilles and Félix Guattari. 1987 [1980]. A Thousand Plateaus: Capitalism and Schizophrenia. Translated by Brian Massumi. Minneapolis, MN: University of Minnesota Press.

Dickard, Norris E. 2002. "Digital-Divide Disconnect." Education Week 21: 40.

Downey, Greg. 2004. "The Place of Labor in the History of Information Technology Revolutions.” Pp. 225-261 in Uncovering Labor in Information Revolutions, 1750-2000, edited by Aad Blok and Greg Downey. Cambridge, U.K.: Cambridge University Press.
Enzensberger, Hans Magnus. 1982a. "Constituents of a Theory of the Media." Pp. 46-76 in H. M. Enzensberger, Critical Essays, edited by Reinhold Grimm and Bruce Armstrong. NY: Continuum.

---. 1982b. “The Industrialization of the Mind." Pp. 3-14 in H. M. Enzensberger, Critical Essays, edited by Reinhold Grimm and Bruce Armstrong. NY: Continuum.

Fernandez, Maria. 1999. "Postcolonial Media Theory." Art Journal 58: 58-73.

Foucault, Michel. 1978 [1975]. Discipline and Punish: The Birth of the Prison. Translated by Alan Sheridan. NY: Random House, Vintage Books.

-.-. 1980. Power/Knowledge: Selected Writings \& Other Interviews 1972-1977. Edited by Colin Gordon. NY: Pantheon Books.

Frankfurt Institute for Social Research. 1972. Aspects of Sociology. Translated by John Viertel. Boston: Beacon Press.

Froehling, Oliver. 1997. "The Cyberspace 'War of Ink and Internet' in Chiapas, Mexico.” Geographical Review 87: 291-307.

Fromm, Erich. 1965 [1941]. Escape from Freedom. NY: Avon Books.

Gibson, William. 1984. Neuromancer. NY: Ace Books.

-.-. 1988. Mona Lisa Overdrive. Toronto: Bantam Books, Spectra.

Giddens, Anthony. 1984. The Constitution of Society: Outline of the Theory of Structuration. Berkeley: University of California Press.

Giovacchini, Saverio. 1998. "'The Land of Milk and Honey': Anti-Nazi Refugees in Hollywood." Historical Journal of Film, Radio and Television 18: 437-444.

Goldberg, Jonah. 1999. "Vote.con: The Perils of 'CyberDemocracy." National Review 51: 28-30.

Habermas, Jürgen. 1983 [1972]. "Walter Benjamin: Consciousness-Raising or Rescuing Critique.” Pp. 129-163 in Jürgen Habermas, Philosophical-Political Profiles, translated by Frederick G. Lawrence. Cambridge, MA: MIT Press.

Hamman, Robin B. 1996. "Rhizome@Internet: Using the Internet as an Example of Deleuze and Guattari's 'Rhizome." http://www.socio.demon.co.uk/rhizome.html. Accessed August 30, 2002.

Harding, Sandra. 1995. "Subjectivity, Experience, and Knowledge: An Epistemology From/For Rainbow Coalition Politics." Pp. 120-136 in Who Can Speak? Authority and Critical Identity, edited by Judith Roof and Robin Wiegman. Urbana, IL: University of Illinois Press.

Harrison, Pat. 2000. "The New Politics of the Cyber Activist." Republican National Committee. http://www.rnc.org/2000/ cyberactivist_042000. Accessed February 10, 2003.

Heidegger, Martin. 1977. “The Question Concerning Technology.” In M. Heidegger, The Question Concerning Technology and Other Essays, translated and edited by William Lovitt. New York: Harper Colophon.

Hellman, Judith, Adler. 1999. "Real and Virtual Chiapas: Magical Realism and the Left." In Necessary and Unnecessary Utopias: Socialist Register 2000, edited by Judith Roof and Robin Wiegman. NY: Monthly Review Press. Available online: http://www.yorku.ca/socreg/hellman.html. Accessed July 13, 2001.

Hirschkop, Ken. 1996. "Democracy and the New Technologies." Monthly Review 48: 88-98. 
Horkheimer, Max. 1989. “Notes on Institute Activities." Pp. 264-6 in Critical Theory and Society: A Reader, edited by Stephen Eric Bronner and Douglas MacKay Kellner. NY: Routledge.

---. 1974 [1947]. Eclipse of Reason. NY: Seabury Press.

Horkheimer, Max and Theodor Adorno. 1973 [1947]. Dialectic of Enlightenment. Translated by John Cumming. NY: Seabury.

Jackson, Derrick. 2002. "President Shrugs at the Digital Divide." Boston Globe July 17; p. A23.

Jarvis, Brian. 1998. Postmodern Cartographies: The Geographical Imagination in Contemporary American Culture. NY: St. Martin's Press.

Jay, Martin. 1973. The Dialectical Imagination: A History of the Frankfurt School and the Institute of Social Research, 19231950. Boston: Little, Brown \& Co.

---. 1984. Adorno. Cambridge, MA: Harvard U.P.

Kalathil, Shanthi and Taylor C. Boas. 2003. Open Networks, Closed Regimes: The Impact of the Internet on Authoritarian Rule. NY: Carnegie Endowment for International Peace.

Katyal, Neal. 2001. "Testimony before the Senate Judiciary Committee, 'DOJ Oversight: Preserving Our Freedoms While Defending Against Terrorism.” November 28, 2001. www.senate.gov/ judiciary/te112801f-katyal.htm. Accessed December 13, 2001.

Kaufman, Robert. 2002. “Aura, Still.” October, 99: 45-81.

Kellner, Douglas. n.d. "Baudrillard: A New McLuhan?” www. gseis.ucla.edu/faculty/kellner/Illumina\%20Folder/kell26.htm. Accessed July 11, 2004.

-.--. 1995. Media Culture: Cultural Studies, Identity, and Politics Between the Modern and the Postmodern New York: Routledge.

---. 1997. "Intellectuals, the New Public Spheres, and TechnoPolitics," New Political Science, Nr. 41-42.

-.-. 1999. "Virilio, War, and Technology: Some Critical Reflections." Theory, Culture \& Society, 16: 103-126. Available online: www.gseis.ucla.edu/faculty/kellner/Illumina $\% 20$ Folder/kell29.htm. Accessed July 11, 2004.

Kendall, Lori. 1998. "Meaning and Identity in 'Cyberspace': The Performance of Gender, Class, and Race Online.” Symbolic Interaction 21: 129-153.

King, Anthony. 1998. "Baudrillard's Nihilism and the End of Theory.” Telos 112: 89-106.

Klein, Naomi. 2000. No Logo. London: Flamingo.

Kroker, Arthur and David Cook. 1986. The Postmodern Scene: Excremental Culture and Hyper-Aesthetics. NY: St. Martin's Press.

Laclau, Ernesto and Chantal Mouffe. 1985. Hegemony and Socialist Strategy: Towards a Radical Democratic Politics. London: Verso.

Laudon, Kenneth. 1986. The Dossier Society: Value Choices in the Design of National Information Systems. NY: Columbia U.P.

Lefebvre, Henri. 1991 [1974]. The Production of Space. Translated by Donald Nicholson-Smith. Oxford: Blackwell.

Louw, Eric. 2001. The Media and Cultural Production. London: SAGE Publications.

Luke, Timothy W. 1991. "Power and Politics in Hyperreality: The Critical Project of Jean Baudrillard.” Social Science Journal 28: 347-368.

Lyon, David. 1994. The Electronic Eye: The Rise of Surveillance Society. Minneapolis, MN: University of Minnesota Press.
..-. 2001. "Surveillance after September 11." Sociological Research Online 6. http://www.socresonline.org.uk/6/3/lyon. html. Accessed September 2, 2002.

Madigan, Michelle. 2002. "Dreaming of a Digital Democracy." PCWorld.com. November 5. www.pcworld.com/resource/ printable/article/0,aid,106734,00.asp. Accessed April 28, 2003.

Marcuse, Herbert. 1966 [1964]. One-Dimensional Man. Boston: Beacon Press.

---. 1969. An Essay on Liberation. Boston: Beacon Press.

-.-. 1978 [1941]. "Some Social Implications of Modern Technology." Pp. 138-162 in The Essential Frankfurt School Reader, edited by Andrew Arato and Eike Gebhardt. NY: Urizen Books.

McLuhan, Marshall. 1964. Understanding Media: The Extension of Man. Cambridge, MA: MIT Press.

Morrow, Raymond A. 1994. Critical Theory and Methodology. Thousand Oaks, CA: SAGE Publications.

Murphy, Brian Martin. 2002. "A Critical History of the Internet." Pp. 27-45 in Critical Perspectives on the Internet, edited by Greg Elmer. Lanham, MD: Rowman \& Littlefield.

Negroponte, Nicholas. 1995. Being Digital. NY: Vintage Books. Norris, Pippa. 2001. The Digital Divide: Civic Engagement, Information Poverty and the Internet in Democratic Societies. NY: Cambridge University Press.

Nunes, Mark. 1995. "Baudrillard in Cyberspace: Internet, Virtuality, and Postmodernity." Style 29: 314-327.

Offe, Claus. 1974. "Structural Problems of the Capitalist State." In German Political Studies, Vol. 1, edited by Klaus von Beyme. London: Sage Publications.

Ornstein, Norman. 2000. "Deliberative Democracy Headed for the 'Dark Side?' State Legislatures 26: 20-3.

Patton, Paul. 2001. "Gilles Deleuze and Félix Guattari." Pp. 205-215 in Profiles in Contemporary Social Theory, edited by Anthony Elliot and Bryan S. Turner. London: SAGE Publications.

Peterson, Shane. 2002. "England Tests E-Voting." Government Technology. http://www.govtech.net/magazine/story. phtml ?id=29354. Accessed April 28, 2003.

Pitt, Joseph C. 2000. Thinking about Technology: Foundations of the Philosophy of Technology. NY: Seven Bridges Press.

Poster, Mark. 1990. The Mode of Information. Cambridge, UK: Polity Press.

---. 2001a. "Citizens, Digital Media and Globalization." Mots Pluriels, Nr. 18. http://www.arts.uwa.edu.au/MotsPluriels/ MP1801mp.html. Accessed February 9, 2002.

----. 2001b. What's the Matter with the Internet? Minneapolis, $\mathrm{MN}$ : University of Minnesota Press.

Postman, Neil. 1993. Technopoly: The Surrender of Culture to Technology. NY: Vintage Books.

Postmes, Tom, Russell Spears and Martin Lea. 1998. "Breaching or Building Social Boundaries? Side-effects of ComputerMediated Communication." Communication Research 25: 689-718.

Raulet, Gerard. 1991. "The New Utopia: Communication Technologies." Telos 87: 39-59.

Record Industry Association of America (RIAA). 2004. "New Wave of Illegal File Sharing Lawsuits Brought By RIAA." http://www.riaa.com/news/newsletter/042804.asp. Accessed: May 12, 2004.

Republican National Committee. 2002. "Campaigns and ePolitics.” Rising Tide. http://www.rnc.org/newsroom/ risingtide/eCampaigns.htm. Accessed: February 10, 2002. 
Rich, Adrienne. 1986. "Notes toward a Politics of Location." In Adrienne Rich, Blood, Bread, and Poetry: Selected Prose, 1979-1985. NY: W.W. Norton. Available online: http:// www.medmedia.org/review/numero2/en/art3.htm. Accessed August 18, 2002.

Saco, Diana. 2002. Cybering Democracy: Public Space and the Internet. Minneapolis: University of Minnesota Press.

Sandstrom Kent L., Daniel D. Martin, and Gary Alan Fine. 2001. "Symbolic Interactionism at the End of the Century." Pp. 217-231 in Handbook of Social Theory, edited by George Ritzer and Barry Smart. London: SAGE Publications.

Schmidt, James. 1998. "Language, Mythology, and Enlightenment: Historical Notes on Horkheimer and Adorno's Dialectic of Enlightenment.” Social Research 65: 807-838.

Stivale, Charles J. 1994. “The Rhizomatics of Cyberspace." http://lists.village.virginia.edu/ cgi-bin/spoons/archive_ msg.pl?file=deleuze-guattari.archive/d-g_1994/ deleuze Apr. $94 \&$ msgnum $=19 \&$ start $=2419 \&$ end $=2858$ and http://lists.village.virginia.edu/cgi-bin/spoons/archive_ msg.pl?file=deleuze-guattari.archive/ d-g_1994/deleuze Apr.94\&msgnum $=20 \& s t a r t=2859 \&$ end $=3260$. Accessed July 11, 2004.

Sunstein, Cass. 2001. Republic.com. Princeton: Princeton U.P.

Thompson, John B. 1995. The Media and Modernity: A Social Theory of the Media. Stanford, CA: Stanford U.P.

Thrift, Nigel. 1996. "New Urban Eras and Old Technological Fears: Reconfiguring the Goodwill of Electronic Things." Urban Studies, 33: 1463-93.

Tsagarousianou, Roza, Damian Tambini and Cathy Bryan. 1998. Cyberdemocracy: Technology, Cities and Civic Networks. London: Routledge.

Turkle, Sherry. 1995. Life on the Screen: Identity in the Age of the Internet. NY: Simon \& Schuster, Touchstone Books.
Vinge, Vernor and James Frenkel (eds.). 1999. True Names and the Opening of the Cyberspace Frontier. New York : Tor.

Virilio, Paul. n.d. "Cyberesistance Fighter: An Interview with Paul Virilio." Interviewed by David Dufresne. www.apres-coup.org/ archives/articles/virilio.html. Accessed May 30, 2004.

-.--. 1994. "Cyberwar, God And Television: Interview with Paul Virilio [by Louise Wilson].” www.ctheory.net/text_file. asp?pick=62. Accessed July 11, 2004).

---. 1995. "Speed and Information: Cyberspace Alarm!" www. ctheory.net/text_file.asp?pick=72. Accessed July 11, 2004.

---. 1996 [12 June]. "The Silence of the Lambs: Paul Virilio in Conversation [with Carlos Oliveira]." www.ctheory.net/text file.asp?pick=38. Accessed July 11, 2004.

-.-- 1997 [1995]. Open Sky. Translated by Julie Rose. London: Verso.

Warf, Barney and John Grimes. 1997. "Counterhegemonic Discourses and the Internet.” Geographical Review 87: 259-274.

Weare, Christopher, Juliet Musso, and Matthew Hale. 1999. "Electronic Democracy and the Diffusion of Municipal Web Pages in California." Administration \& Society 31: 3-27.

Wiggershaus, Rolf. 1995 [1986]. The Frankfurt School: Its History, Theories, and Political Significance. Translated by Michael Robertson. Cambridge, MA: MIT Press.

Wray, Stefan. 1998. "Rhizomes, Nomads, and Resistant Internet Use." http://www.nyu.edu/projects/wray/RhizNom.html. Accessed August 30, 2002.

Zaslow, Jeffrey. 2002. "If TiVo Thinks You Are Gay, Here's How to Set It Straight." Wall Street Journal November 26. http://online. wsj.con/article_email/0,,SB1038261936872356908,00.html. Accessed December 8, 2002. 